\title{
The potential threat of branched broomrape for California processing tomato: A review
}

\author{
After a 40-year absence, branched broomrape has reappeared in commercial California tomato \\ fields, raising concern and prompting the search for integrated approaches to management.
}

by O. Adewale Osipitan, Bradley D. Hanson, Yaakov Goldwasser, Matthew Fatino and Mohsen B. Mesgaran

Online: https://doi.org/10.3733/ca.2021a0012

\section{Abstract}

Branched broomrape (Phelipanche ramosa), a parasitic weed that was the focus of a \$1.5 million eradication effort four decades ago in California, has recently re-emerged in tomato fields in several Central Valley counties. Processing tomatoes are important to the California agricultural economy; the state produced over $90 \%$ of the 12 million tons of tomatoes grown in the United States in 2018. Branched broomrape is listed as an "A" noxious weed by the California Department of Food and Agriculture (CDFA); discovery of broomrape in California tomato fields leads to quarantine and crop destruction without harvest, resulting in significant economic loss to growers. In countries where broomrape is common, yield reductions caused by this parasitic weed can range from moderate to $80 \%$, depending upon the infestation level, host and environmental conditions. Developing a detailed understanding of the biology of this weed under local conditions is an important step towards developing effective management plans for California. In this review, we discuss branched broomrape in the context of California production systems, particularly of tomato. We also discuss the potential management practices that could help to prevent or reduce the impacts of branched broomrape in tomatoes and other host crops. rocessing tomatoes are important to the California agricultural economy; in 2018, California accounted for over $90 \%$ of the 12 million tons of tomatoes grown in the United States (USDA NASS 2019). Some of the most potentially damaging pests of tomato include the weedy broomrapes (Orobanche and Phelipanche spp.), which have recently made an appearance in several California tomato fields after a 40 -year hiatus. While broomrape is not currently at levels that can impact yield, presence in a field causes a large economic loss to growers because of the weed's status as a quarantine pest. The establishment and spread of broomrape in California tomato produc tion regions could cause severe consequences for individual growers and the entire tomato industry.

Broomrapes are obligate root parasitic plants that can cause devastating damage to tomatoes and many other economically important broadleaf crops. These weeds use a modified root, called a haustorium, to fuse into a host plant root and extract nutrients and water. This greatly reduces productivity and sometimes kills the host. Globally, seven broomrape species have been identified that can cause damage to crops. Of

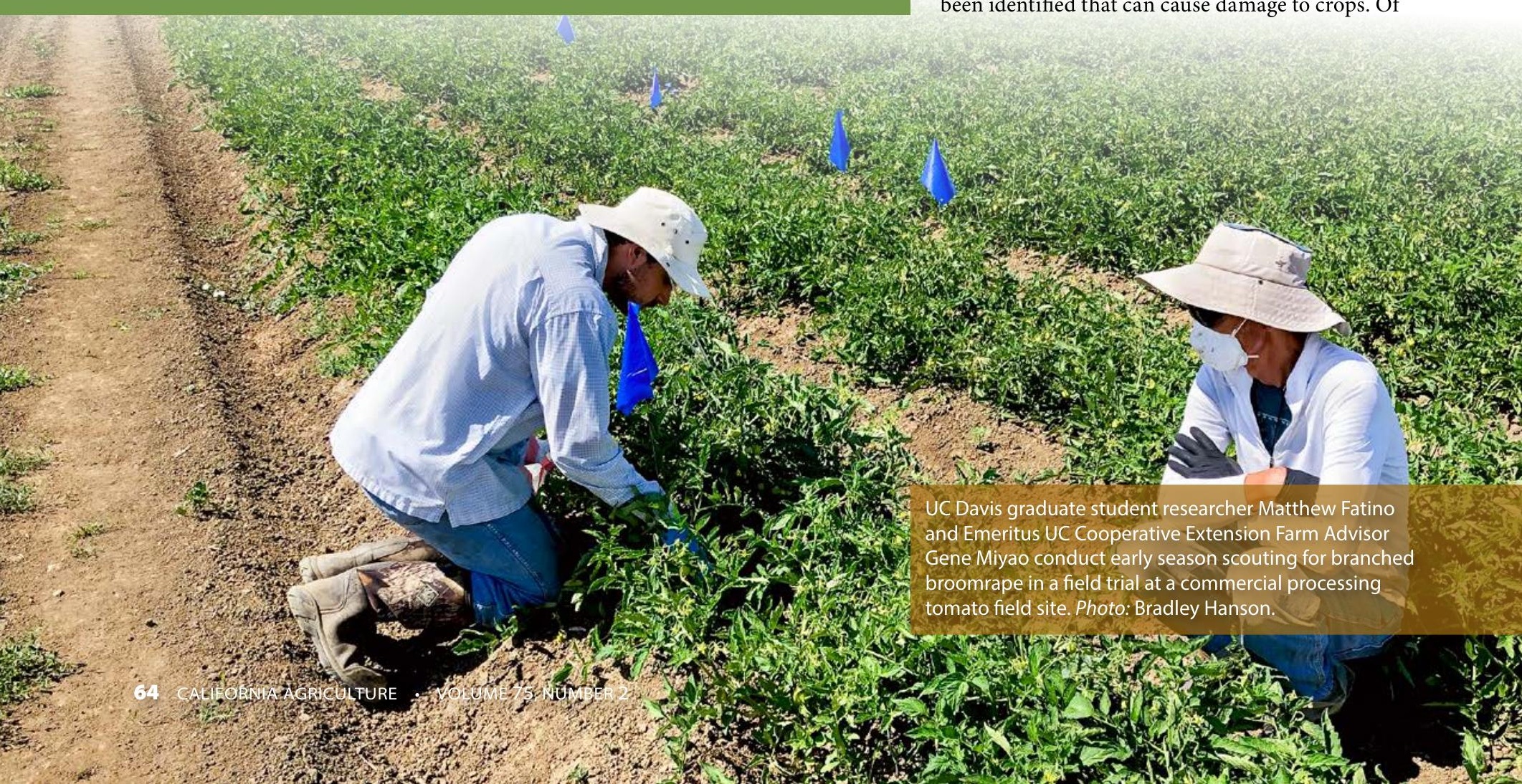


these, small broomrape (Orobanche minor), Louisiana broomrape (Orobanche ludoviciana), Egyptian broomrape (Phelipanche aegyptiaca) and branched broomrape (Phelipanche ramosa) are known to be economically important pests in the United States (Jain and Foy 1989; Miyao 2016).

Tomato is highly susceptible to both branched broomrape and Egyptian broomrape. (A comparison of these broomrapes is shown in table 1.) Branched broomrape is currently classified in California as an " $\mathrm{A}$ " pest. An "A" pest is an organism of known economic importance subject to state-enforced action involving "eradication, quarantine regulation, containment, rejection, or other holding action" (CDFA 2020). The discovery of branched broomrape in a commercial tomato field leads to quarantine and crop destruction without harvest; processers will not accept a load of tomatoes from an infested field.

Egyptian broomrape, which, like branched broomrape, has been detected in some California tomato fields (Miyao 2016), is listed as a "Q" species. "Q" species have a temporary " $A$ " classification pending determination of permanent rating by the state. Though Egyptian broomrape is currently considered less of a threat to California tomato crops than branched broomrape, Egyptian broomrape is also highly destructive. Studies in Israel showed that at high infestation levels ( 100 shoots per square meter $\left.\left[\mathrm{m}^{2}\right]\right)$, Egyptian broomrape can cause processing tomato yield losses as high as $70 \%$ (fig. 1). In Chile and Israel, annual economic losses in tomato due to Egyptian broomrapes have been estimated at $\$ 5$ and $\$ 200$ million, respectively (Hershenhorn et al. 2009).

Globally, branched broomrape is one of the most damaging and widespread of the weedy broomrape species, infesting nearly 6 million acres (about 2.6 million hectares) of broadleaf crops across Asia, the Mediterranean basin and North Africa (Mauromicale et al. 2008) (fig. 2). Branched broomrape infests a wide range of crops including tomato, cabbage, potato, eggplant, carrot, pepper, beans, celery, peanut and sunflower (table 2). A broomrape-parasitized plant suffers growth and yield reduction, and death can result in cases of severe infestation. Yield reduction can be significant depending on the level of infestation, susceptibility of the host and environmental conditions (Bernhard et al. 1998; Kogan 1994). Growers have reported up to $80 \%$ tomato crop loss due to branched broomrape in Chile (Kogan 1994). This is highly concerning given the similarity in tomato production systems and broomrape species with California.

\section{The spread of branched broomrape}

Branched broomrape was first documented in Europe in the 17th century (GBIF 2019), and is now present in 24 countries in Europe, North and South America, Africa and Asia (GBIF 2019; Mohamed et al. 2006). Most of the countries or locations where branched broomrape is reported have a Mediterranean climate, with warm-dry summers and rainy winters (fig. 2). In the United States, branched broomrape was first reported in 1890 and, since then, over 150 occurrences have been documented (GBIF 2019; Musselman 1996). Reports of branched broomrape in the United States have been increasing, from seven occurrences in 2015 to 65 in 2019 (GBIF 2019), and it has been documented in Texas, Virginia, South Carolina, Illinois, New Jersey, Tennessee, Kentucky, Alabama and California (GBIF 2019; USDA-APHIS 2019). In California, branched broomrape was first seen in Butte County (1903) and later in Alameda County (1929) (Hrusa 2008).

TABLE 1. Comparing branched and Egyptian broomrape*

\begin{tabular}{|c|c|c|}
\hline & Branched broomrape & Egyptian broomrape \\
\hline Branching & Has branched stalk/shoot & Has branched stalk/shoot \\
\hline Stalk height & $\begin{array}{l}\text { Usually } 15-20 \mathrm{~cm} \text { tall, but can be } \\
\text { up to } 30 \mathrm{~cm}\end{array}$ & Usually $20-30 \mathrm{~cm}$ tall or more \\
\hline $\begin{array}{l}\text { Peculiar } \\
\text { morphology }\end{array}$ & $\begin{array}{l}\text { No leaves and no green color on } \\
\text { the whole plant }\end{array}$ & $\begin{array}{l}\text { No leaves and no green color on the } \\
\text { whole plant }\end{array}$ \\
\hline \multirow[t]{5}{*}{ Flowers } & $\begin{array}{l}\text { 1. Flowers are merged with outer } \\
\text { part appearing pale purple. }\end{array}$ & $\begin{array}{l}\text { 1. Flowers are merged with outer part } \\
\text { appearing pale blue or purple. }\end{array}$ \\
\hline & $\begin{array}{l}\text { 2. White cushions appear on lower } \\
\text { lobe close to the base. }\end{array}$ & $\begin{array}{l}\text { 2. White cushions appear on lower } \\
\text { lobe close to the base. }\end{array}$ \\
\hline & $\begin{array}{l}\text { 3. Flower tubes are widest at the } \\
\text { top but narrowest at the base. }\end{array}$ & $\begin{array}{l}\text { 3. Flower tubes are widest at the top } \\
\text { but narrowest at the base. }\end{array}$ \\
\hline & $\begin{array}{l}\text { 4. Length of flower is commonly } \\
\text { less than } 20 \mathrm{~mm} \text {. }\end{array}$ & $\begin{array}{l}\text { 4. Length of flower is commonly } \\
\text { longer than } 20 \mathrm{~mm} \text {. }\end{array}$ \\
\hline & $\begin{array}{l}\text { 5. Anthers are sparsely hairy at } \\
\text { the base. }\end{array}$ & 5. Anthers are densely hairy. \\
\hline
\end{tabular}

* Molecular markers have been developed to distinguish between branched and Egyptian broomrape.

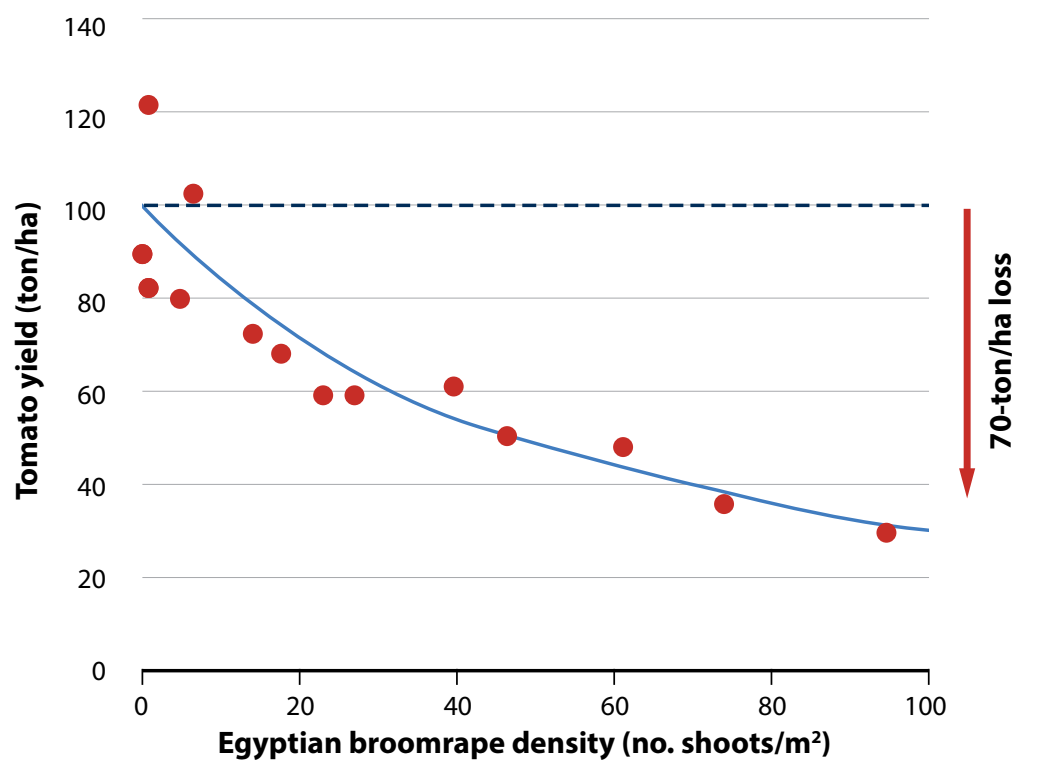

FIG. 1. Tomato yield loss caused by Egyptian broomrape density (H. Eizenberg, unpublished data; used with permission). 


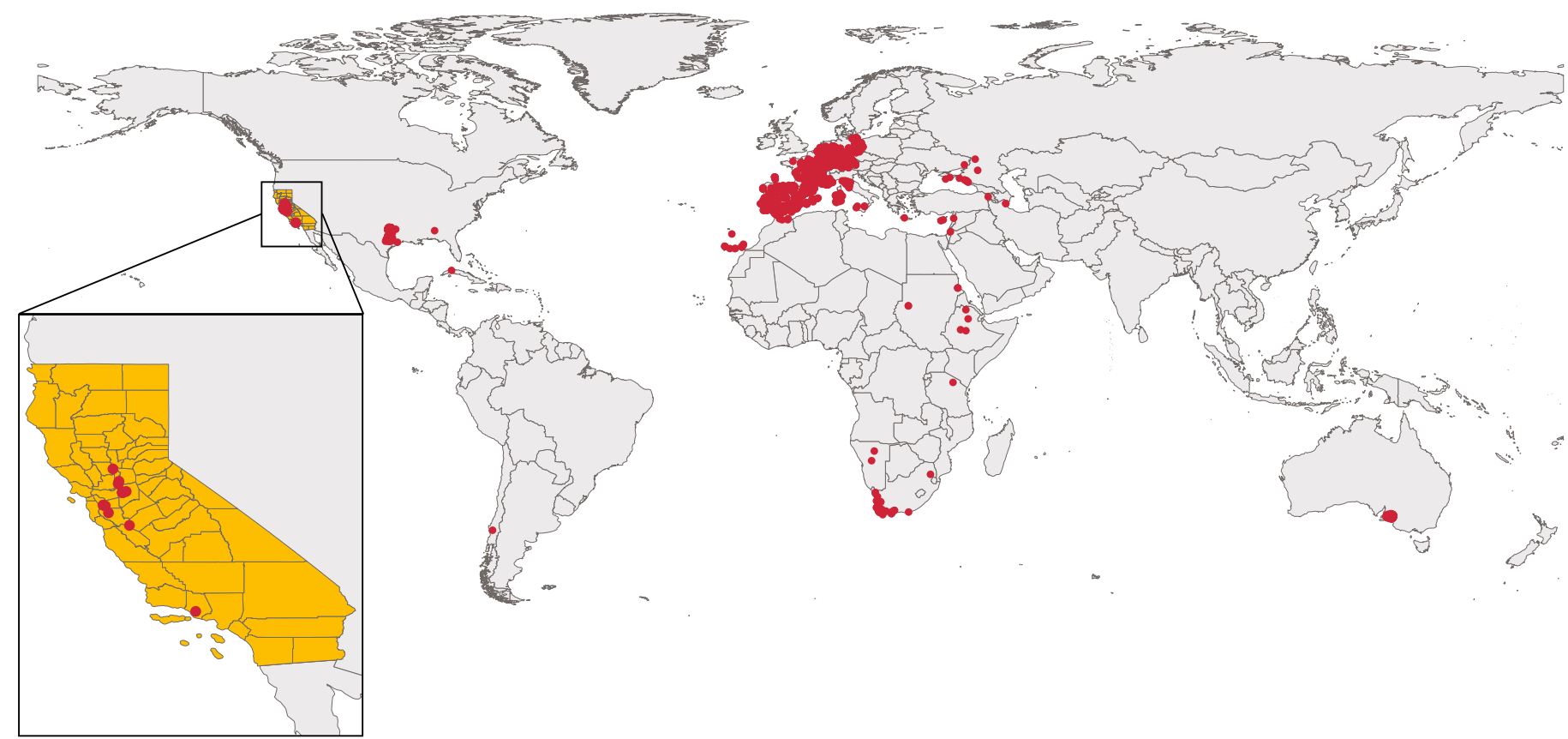

FIG. 2. Global distribution of branched broomrape. Data source: Calflora 2019, GBIF 2019 and ALA 2020.

TABLE 2. Host plants for branched broomrape relevant to California

\begin{tabular}{|c|c|c|c|}
\hline Common name & Scientific name & Family & Reference \\
\hline Cabbage & Brassica oleracea & Brassicaceae & Boari and Vurro 2004 \\
\hline Canola & Brassica napus & Brassicaceae & Benharrat et al. 2005 \\
\hline Carrot & Daucus carota L. & Apiaceae & Mauromicale et al. 2005 \\
\hline Celery & Apium graveolens L. & Apiaceae & Americanos 1991 \\
\hline Chickpea & Cicer arietinum & Fabaceae & Qasem and Foy 2007 \\
\hline Clovers & Trifolium spp. & Fabaceae & Amri et al. 2013 \\
\hline Eggplant & Solanum melongena $\mathrm{L}$. & Solanaceae & Virtue et al. 2014 \\
\hline Faba bean & Vicia faba & Fabaceae & Sauerborn and Saxena 1986 \\
\hline Hemp & Cannabis sativa $\mathrm{L}$. & Cannabaceae & Gonsior et al. 2004 \\
\hline Lentil & Lens culinaris Medik & Fabaceae & Buschmann et al. 2005 \\
\hline Lettuce & Lactuca sativa & Asteraceae & Panetta and Lawes 2007 \\
\hline Parsley & Petroselinum crispum & Apiaceae & Cochavi et al. 2015 \\
\hline Parsnip & Pastinaca sativa & Apiaceae & Kasasian 1971 \\
\hline Peanut & Arachis hypogaea L. & Fabaceae & Jain and Foy 1989 \\
\hline Pepper & Capsicum fruitisence & Solanaceae & Qasem 2009 \\
\hline Potato & Solanum tuberosum $\mathrm{L}$. & Solanaceae & Haidar et al. 2003 \\
\hline Squash & Cucurbita pepo & Cucurbitaceae & Virtue et al. 2014 \\
\hline Sunflower & Helianthus annuus L. & Asteraceae & Karačić et al. 2010 \\
\hline Tobacco & Nicotiana tabacum L. & Solanaceae & Lolas 1994 \\
\hline Tomato & Solanum lycopersicum L. & Solanaceae & Mauromicale et al. 2008 \\
\hline
\end{tabular}

Eventually it spread to other counties in California, including Colusa, Sacramento, San Benito, Santa Clara, San Joaquin, Ventura and Yolo (Calflora 2019; GBIF 2019; fig. 2).

A severe infestation of branched broomrape in the Sacramento Valley in 1959 prompted an intervention that involved soil fumigation with methyl bromide; this was as an industry-led effort funded through a legislative marketing order program (Jain and Foy 1989; Wilhelm 1965). The effort, which lasted from 1973 to 1982 and cost over \$1.5 million (CTRI 2019), involved research, intensive field surveys and fumigation of infested fields and equipment to target the soil seedbank. As a result of those endeavors, branched broomrape became a less significant problem. Recently, however, this parasitic weed has been detected in tomato fields in Yolo, Solano and San Joaquin counties (Miyao 2016; figs. 2 and 3).

The cause of the re-emergence of branched broomrape remains unclear, although re-introduction or recurrence from long-dormant seed in the soil and subsequent spread are the most likely explanations. The re-emergence of this species in California is of concern to the processing tomato industry for many reasons: (1) the demonstrated global vulnerability of tomato to branched broomrape parasitism; (2) the similarity of California's climate to the species' native climate; (3) repeated cultivation of processing tomato in the same fields; (4) the cultivation of a wide range of hosts besides tomato (e.g., carrot, sunflower, safflower) in California; (5) intensive agricultural practices that could rapidly spread broomrape seeds to uninfested fields; (6) the plant's prolific production of tiny seeds 
that can easily disperse via machinery and irrigation water in the highly mechanized and irrigated cropping systems of California; (7) the ability of seeds to persist in the absence of hosts due to seed longevity of more than 20 years; (8) the difficulty of using conventional means of weed control, such as cultivation and contact herbicides, because so much of the plant's lifespan occurs underground; (9) the lack of some known important management tools (e.g., herbicides known to be effective in controlling broomrapes) because they are not yet registered or tested in California; and (10) regulatory and environmental challenges with soil fumigation practices.

\section{Life cycle and physical characteristics}

Branched broomrape is a holoparasite, meaning that it obtains all its nutrients from the host. Seed germination depends on the presence of a suitable host plant (Musselman 1996) and on prevailing environmental conditions. Seeds need to undergo a pre-conditioning period in the form of warm stratification before they can germinate (Fernández-Aparicio et al. 2016). The pre-conditioning period requires moist and warm $\left(59^{\circ} \mathrm{F}\left[15^{\circ} \mathrm{C}\right]\right.$ to $\left.68^{\circ} \mathrm{F}\left[20^{\circ} \mathrm{C}\right]\right)$ environmental conditions from 5 to 21 days. The conditioned seed then can germinate in response to a signaling compound (strigolactone) released from the host plant root (Joel

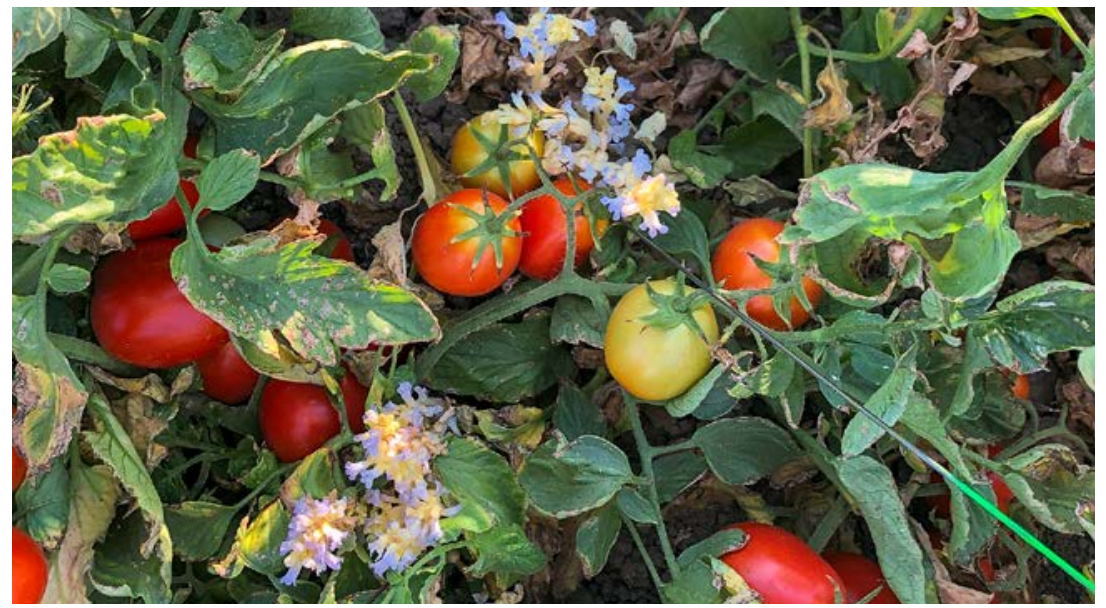

FIG. 3. Branched broomrape can be difficult to detect in processing tomato fields due to its small stature. Its extended period of emergence and rapid progression from emergence to flowering (shown here) to having mature seed further complicate control strategies. Photo: Matthew Fatino.

et al. 2007; fig. 4). If conditions remain conducive, multiple flushes of germination can occur within a single season (fig. 5); however, in the absence of stimulants, these preconditioned seeds re-enter dormancy. As the environment becomes drier, the seed's ability to germinate gradually reduces.

After germination, the radicle of the broomrape seedling grows a few millimeters in length and attaches to the host plant (fig. 4). If it fails to attach to a host

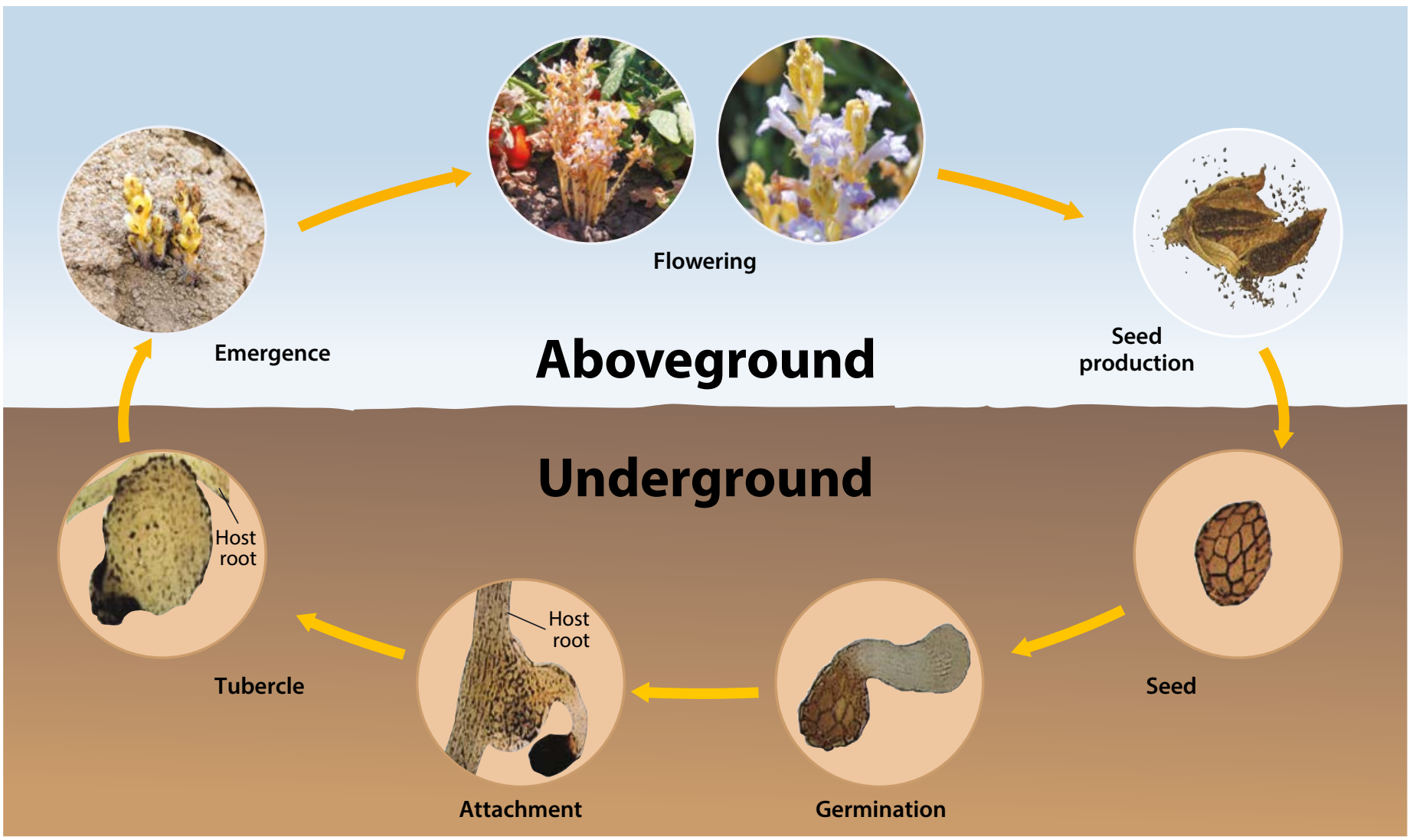

FIG. 4. A summarized life cycle of a branched broomrape. Modified from Eizenberg and Goldwasser (2018). 
within a few days, the radicle exhausts its food reserves and dies (Fernández-Aparicio et al. 2016). Following attachment to the host plant, the radicle develops into a specialized modified root called a haustorium, a plant organ common to all parasitic plants (Buschmann et al. 2005). The haustorium fuses into the vascular system of the host root and serves as the bridge for extraction of nutrients and water from the transport systems (phloem and xylem) of the host (Fernández-Aparicio et al. 2016). Once connected to a host plant, broomrape grows rapidly, forming a tubercle - a storage organ for nutrients and water extracted from the host

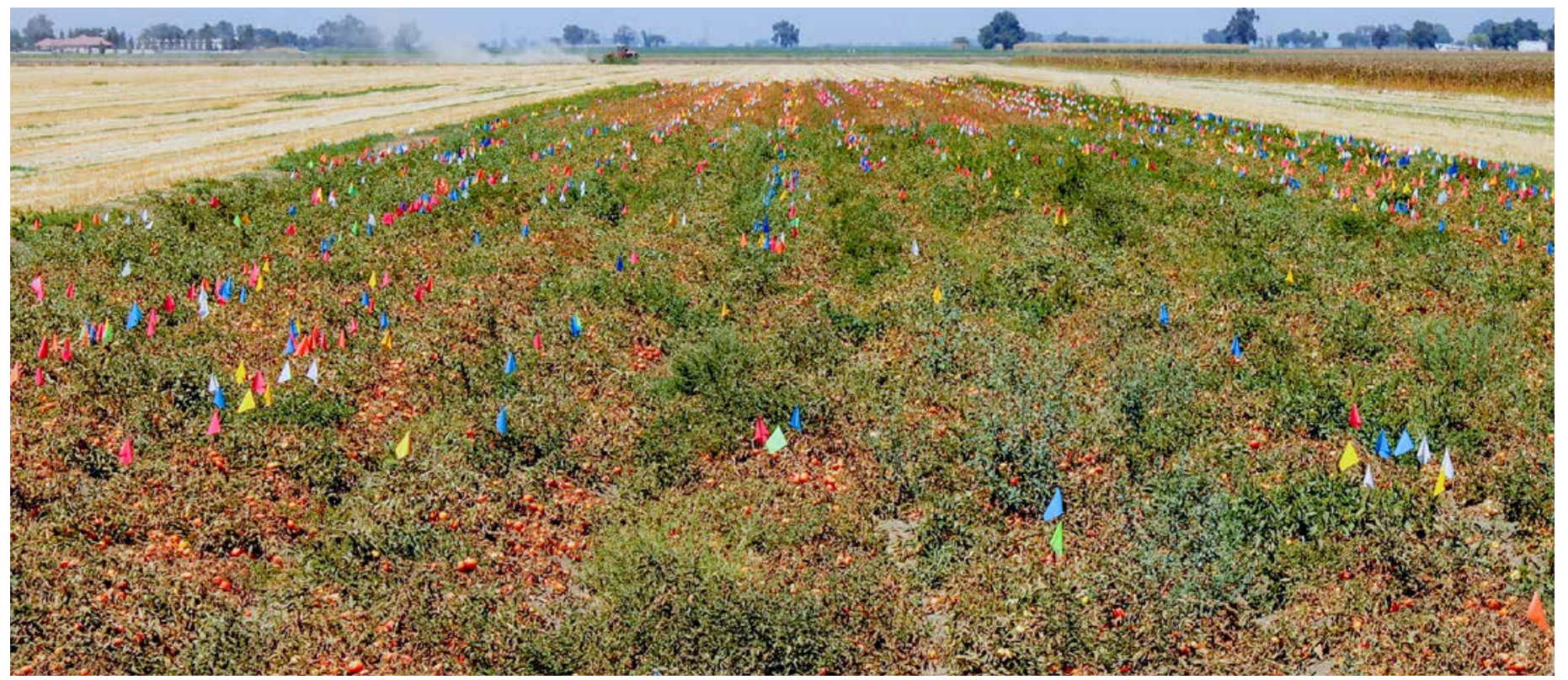

FIG. 5. An infested tomato field with flags of different colors representing multiple flushes of branched broomrape captured weekly from May 29 to July 30, 2020, at Woodland, Yolo County, California. Photo: Matthew Fatino.

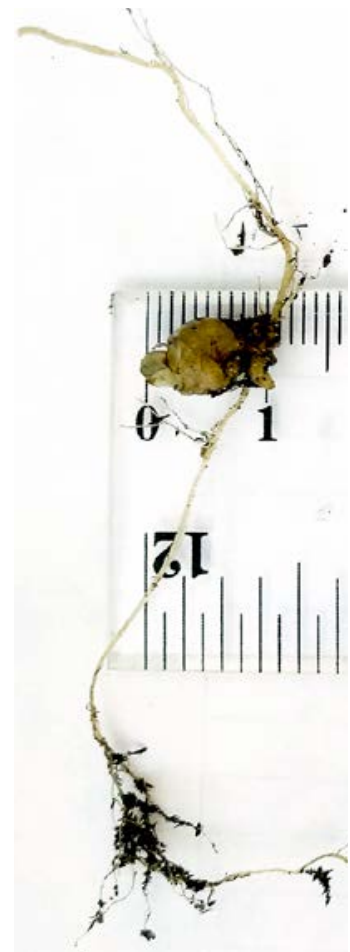

FIG. 6. A 1-cm-long tubercle of branched broomrape on a tomato root. Photo: O. Adewale Osipitan.

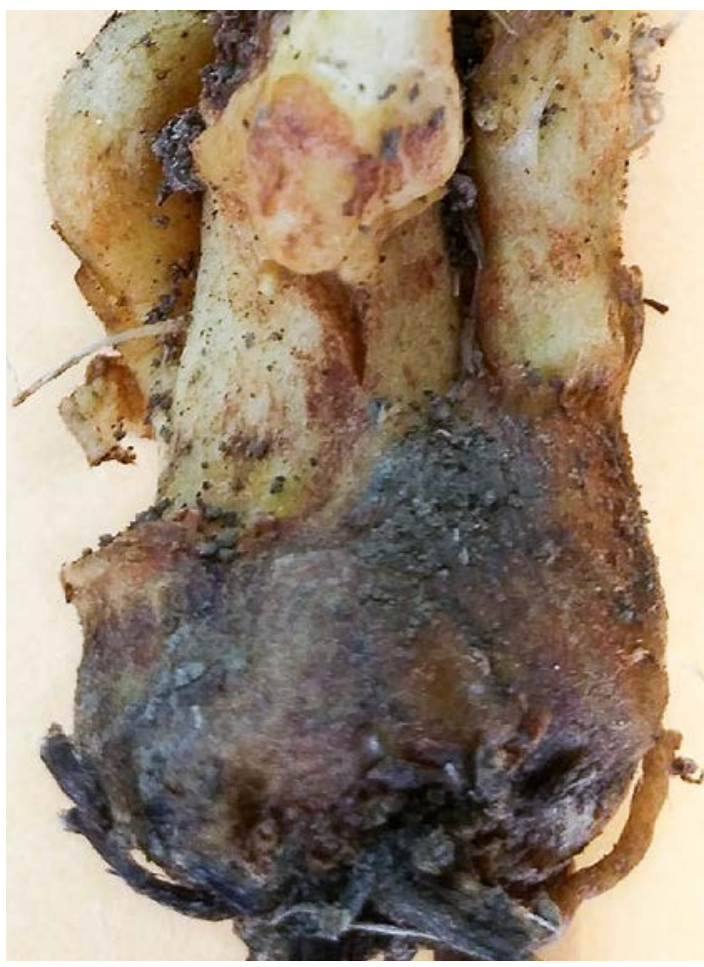

FIG. 7. Tubercle of a weedy broomrape with three shoots. Photo: O. Adewale Osipitan.

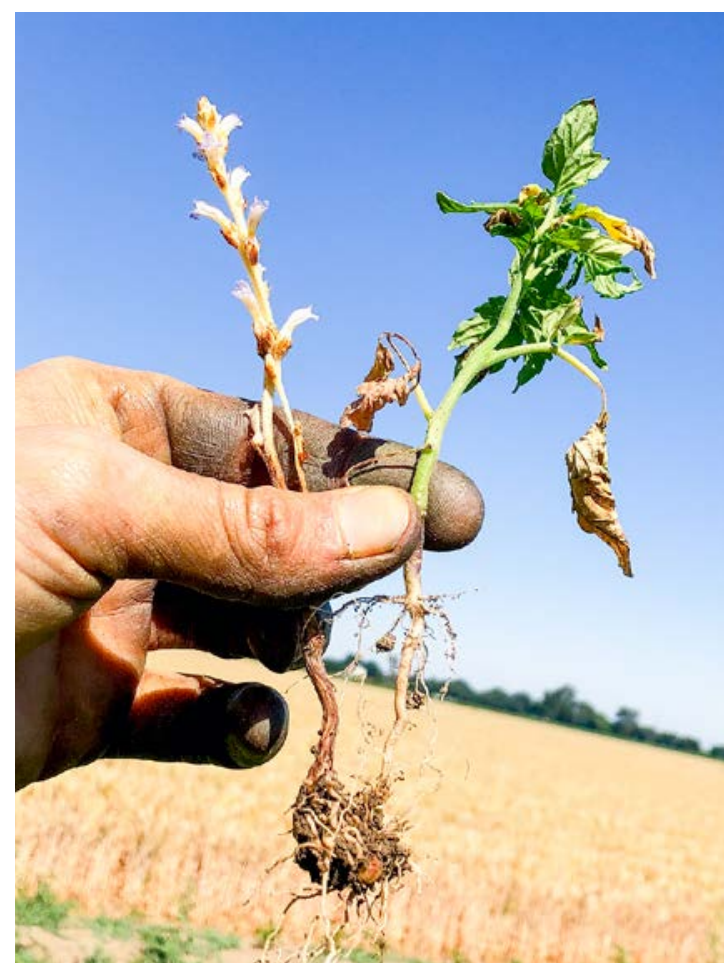

FIG. 8. A branched broomrape plant attached to a volunteer tomato root. Photo: Bradley D. Hanson. 
— underground (figs. 6, 7 and 8). Multiple shoots develop from the tubercle and emerge above the soil surface, then grow to stalks from 6 inches ( 15 centimeter $[\mathrm{cm}])$ to 12 inches $(30 \mathrm{~cm})$ in height (figs. 7 and 9). The shoots, wrapped with alternate bracts, completely lack leaves and chlorophyll. Prior to flowering, young plants look like yellowish spikes (fig. 9).

Flowering begins within 3 to 7 days after a broomrape shoot emerges above the soil surface (fig. 10). Branched broomrape flowers are spike-like, irregular, bisexual and usually pale white to purple in color. The petals of the flower are merged, tubular and have an upper and lower lip (fig. 10). The carpels are usually united to form a single chamber on the upper part of the flower; this chamber matures as a capsule with thousands of very tiny seeds, each smaller ( 0.2 millimeters to 0.4 millimeters) than a grain of sand (fig. 11). Seed production can occur within 14 days after flowering. A mature broomrape plant can produce hundreds of thousands of tan or brown-colored seeds, which can remain dormant and viable for many years $(>20)$ in soil. The entire life cycle, from seed germination to seed production, takes place within the March-to-August growing season of processing tomatoes in California.

\section{Management: An integrated approach}

Effective control of broomrapes is difficult, largely due to its unique biology and complex life cycle. As indicated above, most of the broomrape life cycle occurs below the soil surface, which makes it difficult to detect and control before it causes damage to the host plant. The short time period between emergence and seed dispersal also makes detection and control difficult, while the absence of chlorophyll and photosynthesis limits potential herbicide target sites and complicates chemical management. The tiny, hard-to-detect and abundant seeds, and the ability of the seeds to remain viable for decades, promotes the spread and persistence of branched broomrape in crop production systems. Thus, effective management of broomrape will require a long-term, integrated approach that involves sound understanding of the biology of the parasitic weed and the dissemination of information about management practices to all stakeholders.

\section{Prevention and containment}

Early detection and awareness of a new infestation, rapid reporting of the infestation to the local agricultural commissioner, proper removal of the branched broomrape plants, and management of the seedbank are crucial steps for successful containment and eradication of this parasite. Preventing the spread of branched broomrape is the most important component of the integrated approach to managing the weed. A current containment approach used in California is based on a quarantine regulation that places a recently

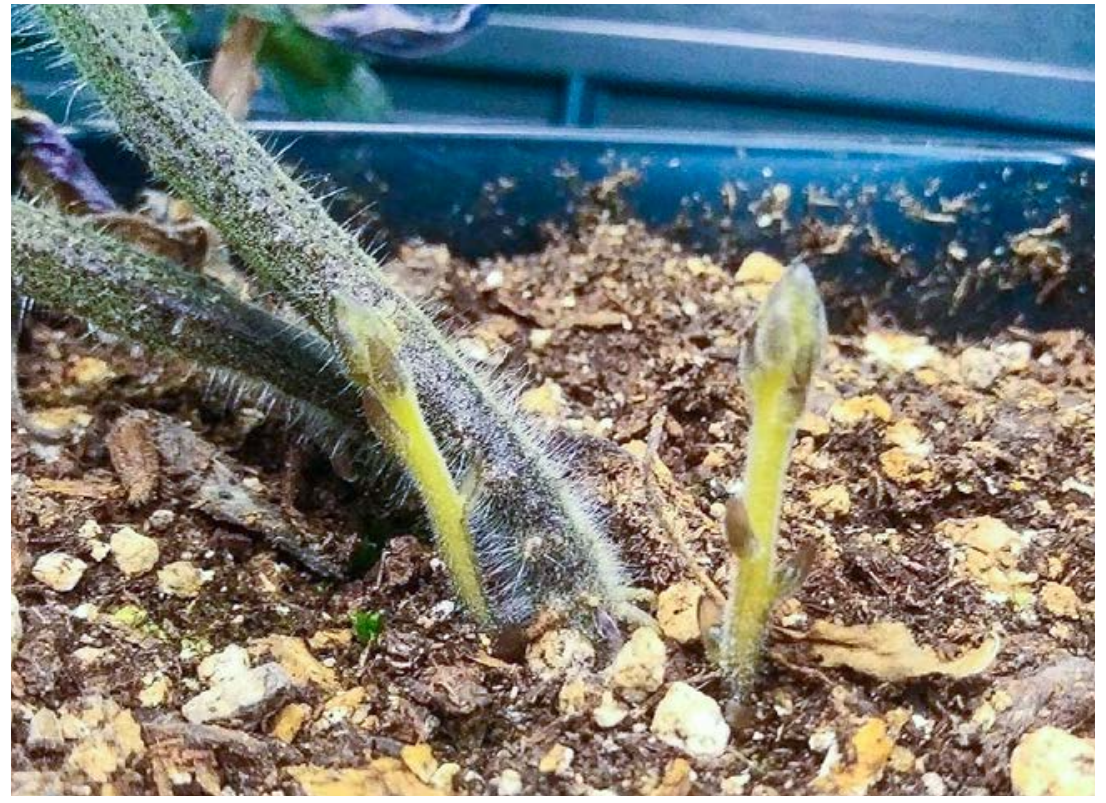

FIG. 9. Recently emerged broomrape shoots just starting to flower. Photo: O. Adewale Osipitan.
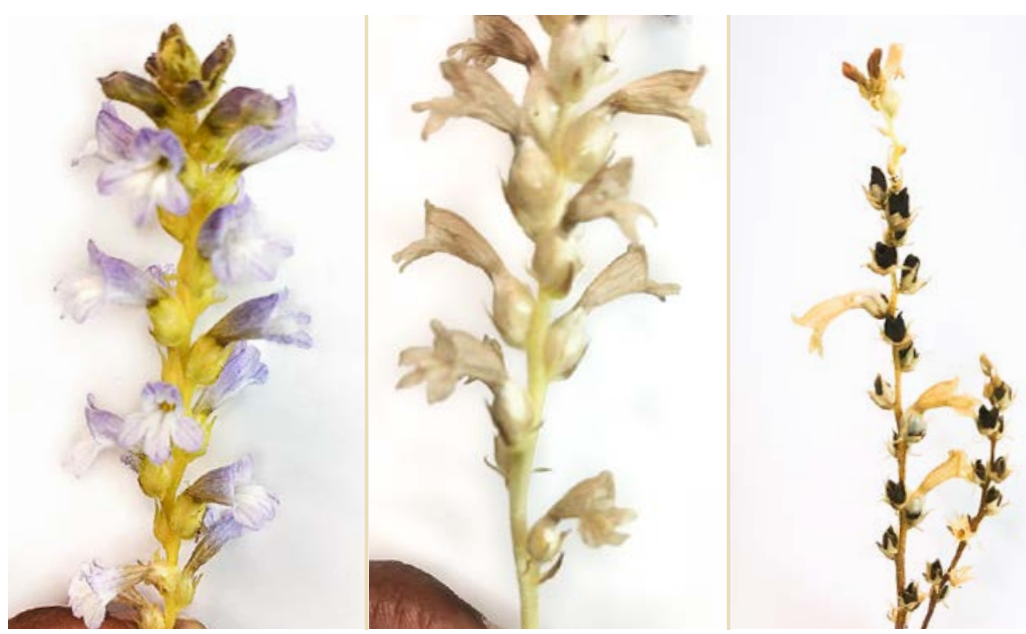

FIG. 10. A branched broomrape plant: flowering (left), maturing (center) and mature capsules (right). Photos: O. Adewale Osipitan.

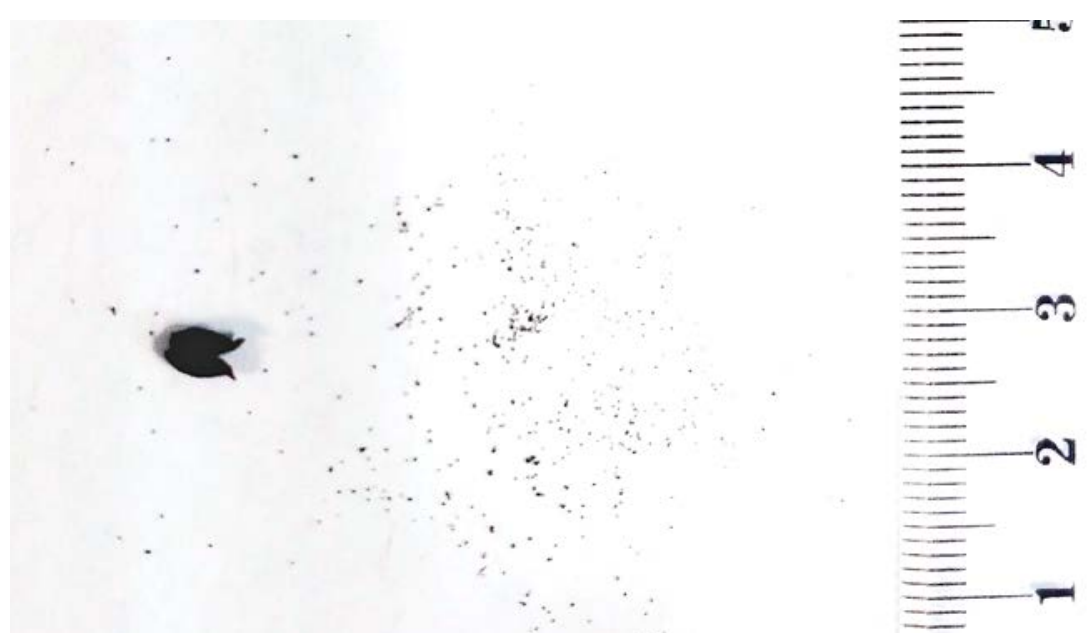

FIG. 11. Tiny branched broomrape seeds $(0.2-0.4 \mathrm{~mm})$ and the single capsule from which the seeds were sourced. Photo: O. Adewale Osipitan. 
[E]ffective management of broomrape will require a long-term, integrated approach that involves sound understanding of the biology of the parasitic weed and the dissemination of information about management practices to all stakeholders.

infested field on hold for a period of at least 2 years; in subsequent years, only rotational crops approved by the local agricultural commissioner may be cultivated in the field.

Upon detection of a new infestation, all branched broomrape plants should be removed carefully (e.g., pulled out of the soil by hand), ideally before they produce seeds. However, because of variability in the plant's growth stages (figs. 3 and 5), seed production might already have occurred by the time they are detected. The application of broad-spectrum herbicides at this stage, although likely to kill both the host plant and parasite, is less likely to affect the seeds. Therefore, the plants should be pulled and placed in plastic bags to minimize seed addition to the seedbank. The bags, tightly sealed, can be left under the sun (solarized) for a few days to promote the degradation of seeds. The plant materials (with or without solarization) can also be burned or destroyed by autoclave.

Weed seeds are often dispersed among fields by human activities, such as the transportation of contaminated farm produce (seeds, fruits and forage), the movement of contaminated vehicles and implements, and the spreading of contaminated soil and manure. Therefore, substantial effort should be made to clean and disinfect all equipment used in a field with broomrape infestation. Equipment sanitation should begin with removal of plant and soil debris manually, as debris not only can contain seeds but can also reduce the effectiveness of disinfectants. Once most of the debris has been removed, chemical disinfection agents can be used on the equipment to kill any remaining seed and pathogens. According to Hershenhorn et al. (2009), several quaternary ammonium products are available for disinfestation (phytosanitation) of farm equipment, such as didecyl dimethyl ammonium chloride, alkyl dimethyl benzyl ammonium chloride, dioctyl dimethyl ammonium chloride, octyl decyl dimethyl ammonium chloride, and ammonium bromide. Commercial products may contain one or a combination of these chemistries. For example, New Development Process (Process NPD; STERIS Corporation, St. Louis, Mo.) is an example of a commercially available product, containing multiple quaternary ammonia, that can be used for disinfection of farm equipment, clothing and shoes against broomrape seeds.

Soil fumigation using methyl bromide is one of the most effective tools to kill broomrape seeds, but due to its environmental toxicity the chemical has been banned and is no longer generally available. Even if methyl bromide were allowed under quarantine restrictions, the cost of treatment would be prohibitive. Other soil fumigants, such as chloropicrin, dazomet, metamsodium, metam-potassium and 1,3-dichloroproprene, may also provide different control levels of broomrape seeds (Eizenberg and Goldwasser 2018; Miyao 2016). However, at this time, few of these fumigants have been evaluated experimentally under California conditions.

\section{Herbicidal control}

Herbicidal control of broomrape can be undertaken using pre-plant and post-plant herbicide applications and/or chemigation (herbicide application through irrigation systems). This is an area of on-going research in California and builds on programs developed in other regions. In processing tomato in Israel, for example, herbicides have been used to effectively and economically manage broomrapes in highly infested fields where eradication is no longer feasible (Eizenberg and Goldwasser 2018). Growers found that pre-plant herbicide applications followed by complimentary post-transplant applications of acetolactate synthaseinhibiting herbicides such as sulfosulfuron (37.5 grams of active ingredient per hectare [g a.i. ha ${ }^{-1}$ ]) provided control ( 90\%) of Egyptian broomrape at both preand post-attached stages in tomato (Eizenberg and Goldwasser 2018). The use of rimsulfuron (37.5 $\mathrm{g}$ a.i. $\mathrm{ha}^{-1}$ ) as a pre-plant incorporated herbicide with a complimentary post-emergence application also provided good suppression ( 70\% control) of broomrape without causing significant damage to tomato plants (Eizenberg and Goldwasser 2018).

Some herbicide application protocols are based on the level of severity of broomrape infestation in tomato. For example, researchers in Israel have developed a thermal time-based decision support system (DSS) named PICKIT that takes into account infestation levels and growing degree days (GDD) since planting to guide the timing and rate of multiple herbicide applications for control of Egyptian broomrape; the system has been applied on a broad commercial scale (Eizenberg and Goldwasser 2018). For severe infestations (more than five broomrape plants per square meter), growers apply sulfosulfuron $\left(37.5 \mathrm{~g}\right.$ a.i. $\left.\mathrm{ha}^{-1}\right)$ three times post-planting at 200, 400 and $600 \mathrm{GDD}$, followed by overhead irrigation $\left(300 \mathrm{~m}^{2}\right)$ complemented by two foliar-applied doses of imazapic ( $4.8 \mathrm{~g}$ a.i. ha ${ }^{-1}$ each) at a later growth stage. The DSS suggests that a medium level of broomrape infestation (three to five plants per square meter) requires a single pre-plant incorporation of sulfosulfuron ( $37.5 \mathrm{~g}$ a.i. ha ${ }^{-1}$ ) before planting tomato, followed by drip chemigation of imazapic (2.4 g a.i. $\mathrm{ha}^{-1}$ ) at 400, 500, 600, 700 and $800 \mathrm{GDD}$, with two additional foliar imazapic applications (4.8 g a.i. ha ${ }^{-1}$, each) at a later growth stage. A similar DSS system is being tested on branched broomrape infestations in processing tomatoes in Chile and California with promising initial results (fig. 5). 
In California, only the rimsulfuron component of the PICKIT system is currently registered for use in processing tomato. Crop safety and registrationsupport research is ongoing in California in an effort to register additional herbicides and application techniques in the event that branched and/or Egyptian broomrape problems expand in scale (Fatino et al. 2019). A preliminary result from this research suggests that no visual injury and yield loss are associated with the use of the PICKIT system in local tomato fields (Fatino et al. 2019).

\section{Cultural practices}

Cultural practice, such as rotating tomato plants with false hosts (trap crops) or non-host crops, could help with seedbank depletion, provided branched broomrape seed is not re-introduced to the field from outside. A trap crop is a species with root exudates that induce broomrape seed germination but the crop does not allow attachment or support broomrape seedling growth and survival. Potential trap crops for branched broomrape that can be used in a rotation are alfalfa (Medicago sativa), cowpea (Vigna unguiculata), green pea (Pisum sativum) and flax (Linum usitatissimum) (table 3). Tomato and other host crops (table 2) should be excluded from the rotation for several years to encourage further depletion of seedbank with no chance of seed production. Since broomrape seed is very sensitive to flooding, incorporation of flooded rice into the crop rotation may also accelerate the depletion of soil seedbank

(Goldwasser and Rodenburg 2013).

Soil fertility management can contribute substantially to the management of branched broomrape. Direct contact with fertilizer, such as urea and ammonium, may be toxic to broomrape, inhibiting seed germination and seedling growth (Fernandez-Aparicio et al. 2016; Westwood and Foy 1999). The negative effect of ammonium on broomrape is due to the plant's limited ability to detoxify the ammonium compound using glutamine synthetase (Fernandez-Aparicio et al. 2016). Application of adequate fertilizer will not only ensure unhindered growth of the tomato plant; it will also minimize the release of the plant's strigolactone, a root exudate that stimulates broomrape germination (Yoneyama et al. 2007). For example, it has been demonstrated that phosphate fertilization negatively impacts branched broomrape seed germination in tomato fields because of reductions in strigolactone exudation (López-Ráez et al. 2008).

Soil solarization has been shown to be an effective alternative to fumigation in reducing broomrape seed viability in areas with sufficiently hot climate. Solarization can significantly increase top soil temperatures up to 6 inches $[15 \mathrm{~cm}]$ in depth when moist soil is covered with transparent polyethylene sheets for a period of one to two months. Dahlquist et al. (2007) reported $100 \%$ seed mortality of several weed species with solarization that raised soil temperature above $45^{\circ} \mathrm{C}$ for at least 96 cumulative hours. Mauro et al. (2005) found that soil solarization for two consecutive summers provided $99 \%$ mortality of viable seeds of branched broomrape in the seedbank without any negative impact on tomato yield. A recent field study conducted at UC Davis confirmed that soil solarization plus organic amends of either tomato pomace or plowed-down tomato plants can be used to substantially reduce the weed seedbank in general in tomato fields (Osipitan et al. 2020), although broomrape was not present at this site. One challenge in using this approach is the need to take tomato fields out of production for several months during the summer growing season in California. Additionally, it is not currently known if the elevated temperatures from solarization would penetrate deeply enough into the soil to provide adequate control of broomrape seed throughout the tomato root zone in an open-field production system.

Other thermal methods of soil disinfestation, such as soil steaming, are another alternative to chemical fumigation. Soil steaming (injecting low-pressure saturated steam into soil) has been shown to be effective in controlling seeds of several weeds and other soil pest in California strawberry production (Fennimore et al. 2014). High soil temperatures of $158^{\circ} \mathrm{F}\left(70^{\circ} \mathrm{C}\right)$ for 30 minutes can be regularly achieved in the field to a depth of 0 to 10 inches $(25 \mathrm{~cm})$ (Fennimore et al. 2014). This treatment seems to be sufficient to kill seeds of many weeds (Fennimore and Goodhue 2016; Melander and Kristensen 2011). Although the effect of this technique on broomrape seed mortality has not been studied, the small seed size of broomrape plants and their lack of protective tissues suggest that broomrape could be vulnerable to steam heating. However, like solarization, it is not known whether the depth of control from soil steaming would be sufficient as part of an eradication strategy for a quarantine pest like branched broomrape.

TABLE 3. Potential trap plants for branched broomrape

\begin{tabular}{|l|l|l|}
\hline Common name & Scientific name & Family \\
\hline Alfalfa & Medicago sativa L. & Fabaceae \\
\hline Caraway & Carum ajowan Benth. et Hook & Apiaceae \\
\hline Castor bean & Ricinus communis L. & Euphorbiaceae \\
\hline Cowpea & Vigna unguiculata L. & Fabaceae \\
\hline Flax & Linum usitatissimum L. & Fabaceae \\
\hline Garlic & Allium sativum L. & Alliaceae \\
\hline Green bean & Phaseolus vulgaris L. & Fabaceae \\
\hline Green gram & Vigna radiata $(\mathrm{L}$.$) Wilczek$ & Fabaceae \\
\hline Green pea & Pisum sativum L. & Fabaceae \\
\hline Lablab bean & Lablab purpureus L. & Fabaceae \\
\hline Ochrus pea & Lathyrus ochrus L. & Fabaceae \\
\hline Sesame & Sesamum indicum L. & Pedaliaceae \\
\hline Soybean & Glycine max L. & Fabaceae \\
\hline Source: Kroschel 2002. & & \\
\hline
\end{tabular}




\section{Physical control}

Physical weed removal, such as hand weeding, particularly for a small infestation, can be part of an integrated approach to broomrape control. California is a state where hand removal of broomrape may be an option given the limited infestation level and widespread use of farm labor. The efficacy of hand weeding is highly dependent on thorough scouting and detection, which can be very difficult given the plant's small stature and the short period between its emergence and seed set (fig. 3). Deep inversion plowing (to more than 12 inches [30 cm]) would bury broomrape seeds to a depth below the soil layer where attachment to tomato root can occur (Eizenberg et al. 2007). However, the dormancy

Therefore, success will depend on significant funding from state or industry sources to offset grower costs in order to ensure grower participation and reporting.

and durability of broomrape seed in the soil seedbank would increase the risk of later broomrape re-occurrences. Physical removal and deep burial could be part of a management strategy if broomrape became too widespread for quarantine

and eradication efforts to be feasible; however, because broomrape is an A-listed pest (zero tolerance), physical removal and deep burial are not likely to provide a sufficient level of control alone.

\section{Biological control}

Biological control involves the use of biological agents or processes to damage seed, kill weedy plant or interfere with parasite-host relationships. A few examples of biological control of broomrapes have been reported in the literature. An insect herbivore, Phytomyza orobanchia, is known to be specific for broomrapes and feeds on broomrape ovules and seeds, thereby reducing broomrape seed production (Fernández-Aparicio et al. 2016). Pathogens such as Fusarium sp. (e.g., Fusarium oxysporum and Fusarium arthrosporiodes) can be incorporated into the soil to control broomrape through an induced cytoplasm metabolism and endosperm cellwall degradation that breaks seed dormancy, thereby depleting the broomrape seedbank (Cohen et al. 2002). Pathogen-based herbicides have been reportedly used to control young seedlings of parasitic weeds (Abbasher and Sauerborn 1992), and these bioherbicides can provide complete control of all emerged broomrapes if formulated with multiple pathogens (Dor and Hershenhorn 2003; Müller-Stöver and Kroschel 2005). However, to date, no research on the applicability of these approaches in California cropping systems and broomrape infestation levels has been conducted, and they are not currently available for use.

Cultivation of resistant tomato varieties would also be an effective approach to prevent parasitic effects of broomrape. Resistance to branched broomrape might be achieved by incorporating traits that prevent haustorium attachment and penetration, or tubercle formation; this approach has been demonstrated in broomrape-resistant sunflower (Velasco et al. 2012). A group of scientists at UC Davis are currently screening a wide range of tomato varieties to determine their resistance to branched broomrape; results from this study could help to determine if enough genetic variability exists in tomato to use conventional breeding approaches to breed for broomrape resistance. Although screening is effective in small plots and is promising in the longer term, at present there are no effective commercial biological measures for broomrape control in tomato.

\section{Conclusion}

The re-emergence and spread of branched broomrape are of great concern in tomato and other susceptible crop production systems in California. At this point in time, the problem is still relatively small. Current efforts are focused on quarantine and eradication using a regulatory approach and soil fumigation. These approaches depend on the reporting of new infestations and generally result in total crop loss to the grower and extremely high treatment costs. Therefore, success will depend on significant funding from state or industry sources to offset grower costs in order to ensure grower participation and reporting. In the event that broomrape problems in California expand beyond what can realistically be managed using quarantine approaches, management and mitigation approaches will be needed just like with other widespread weeds. Other countries have successfully demonstrated that an integrated approach on a long-term basis, involving outreach to growers, field scouting and detection of new infestations, mapping of contaminated areas and fields, equipment sanitation, manipulation of cultural practices and carefully timed herbicide treatments, among other treatments, can effectively reduce yield losses caused by branched broomrape. Significant research efforts are being made by a group of university, industry and regulatory scientists to develop detection and management approaches for branched broomrape and to modify existing approaches from other regions for adaptation in California. CA

O. Adewale Osipitan is Postdoctoral Researcher, UC Davis; B.D. Hanson is UC Cooperative Extension Weed Specialist, UC Davis; Y. Goldwasser is Professor, Hebrew University of Jerusalem, Israel; M. Fatino is Graduate Student, UC Davis; and M.B. Mesgaran is Professor of Weed Science, UC Davis. 


\section{References}

[ALA] Atlas of Living Australia. 2020. Occurrence records download on 2020-08-11. Query: Phelipanche ramose. https://doi. org/10.26197/5f322d545ffd6 (accessed August 10, 2020). Americanos PG. 1991. Control of Orobanche in celery. Technical Bulletin 137. Agricultural Research Institute, Ministry of Agriculture and Natural Resources. Nicosia, Cyprus.

Amri M, Abbes Z, Bouhadida M, Kharrat M. 2013. First report of the parasitic plant Phelipanche ramosa on berseem clover

(Trifolium alexandrinum) in Tunisia. Tunis 8:127-32.

Benharrat H, Boulet C, Theode C, Thalouarn P. 2005. Virulence diversity among branched broomrape (O. ramosa L.) populations in France. Agron Sustain Dev 25:123-28.

Bernhard RH, Jensen JE, Andreasen C. 1998. Prediction of yield loss caused by Orobanche spp. in carrot and pea crops based on the soil seedbank. Weed Res 38:191-97.

Boari A, Vurro M. 2004. Evaluation of Fusarium spp. and other fungi as biological control agents of broomrape (Orobanche ramosa). Biol Control 30:212-19.

Buschmann H, Gonsior G, Sauerborn J. 2005. Pathogenicity of branched broomrape (Orobanche ramosa) populations on tobacco cultivars. Plant Pathol 54:650-56

Calflora 2019. Taxon report 13518: Phelipanche ramosa $\mathrm{L}$. The Calflora Database. Berkeley, CA. www.calflora.org/cgi-bin/ species_query.cgi?wherecalrecnum $=13518$ (accessed November 10, 2020).

[CDFA] California Department of Food and Agriculture. 2020. California Pest Rating. www.cdfa ca.gov/plant/IPC/encyclowee dia/winfo_weedratings.html

Cochavi A, Achdari G, Smirnov E, et al. 2015. Egyptian broomrape (Phelipanche aegyptiaca) management in carrot under field conditions. Weed Technol 29.519-28.

Cohen BA, Amsellem Z, Lev-Yadun SIM, Gressel J. 2002. Infection of tubercles of the parasitic weed Orobanche aegyptiaca by mycoherbicidal Fusarium species. Ann Bot 90:567-78.

[CTRI] California Tomato Research Institute 2019. Recent branched broomrape findings. http://tomatonet.org/img/ uploadedFiles/NewslettersUPDATE/CTRI_2019_NEWSLETTER. pdf
Dahlquist RM, Prather TS, Stapleton JJ. 2007. Time and temperature requirements for weed seed thermal death. Weed Sci 55:619-25

Dor E, Hershenhorn J, Andolfi $A$, et al. 2009. Fusarium verticillioides as a new pathogen of the parasitic weed Orobanche spp. Phytoparasitica 37:361-70.

Eizenberg H, Goldwasser Y. 2018. Control of Egyptian broomrape in processing tomato: A summary of 20 years of research and successful implementation. Plant Dis 102:1477-88.

Eizenberg $\mathrm{H}$, Lande T, Achdari $\mathrm{G}$, et al. 2007. Effect of Egyptian broomrape (Orobanche aegyptiaca) seed-burial depth on parasitism dynamics and chemical control in tomato. Weed Sci 55:152-56.

Fatino M, Mesgaran M, Hanson B. 2019. Evaluation of crop-safety of PICKET system on California-grown processing tomatoes (IR-4 Project: IS00330-19-CA01). http://ucanr. edu/repository/fileaccess. $\mathrm{cfm}$ ?article $=178640 \& \mathrm{p}=$ CFORAQ

Fennimore SA, Martin FN, Miller TC, et al. 2014. Evaluation of a mobile steam applicator for soil disinfestation in California strawberry. HortSci 49(12):154249.

Fennimore SA, Goodhue RE. 2016. Soil disinfestation with steam: A review of economics, engineering, and soil pest control in California strawberry. Int J Fruit Sci 16:71-83.

Fernández-Aparicio M, Reboud X, Gibot-Leclerc S. 2016. Broomrape weeds. Underground mechanisms of parasitism and associated strategies for their control: a review. Front Plant Sci 7:135

[GBIF] Global Biodiversity Information Facility 2019. Phelipanche ramosa Pomel. In Bull SocSci Phys Algerie 11:103. 1874. www.gbif.org/ species/3728894 (accessed November 10, 2020).

Goldwasser Y, Rodenburg J. 2013. Integrated agronomic management of parasitic weed seed banks. In Parasitic Orobanchaceae: Parasitic Mechanisms and Contro/ Strategies. Joel DM, et al. (ed.). Berlin, Heidelberg: Springer. p 393-413.

Gonsior G, Buschmann H, Szinicz G, et al. 2004. Induced resistance - an innovative approach to manage branched broomrape (Orobanche ramosa) in hemp and to bacco. Weed Sci 52:1050-53.
Haidar MA, Bibi W, Sidahmed MM. 2003. Response of branched broomrape (Orobanche ramosa) growth and development to various soil amendments in potato. Crop Prot 22:291-94.

Hershenhorn J, Eizenberg $\mathrm{H}$, Dor E, et al. 2009. Phelipanche aegyptiaca management in tomato. Weed Res 49:34-47.

Hrusa F. 2008. Significant records in botany: branched broomrape. In California Plant Pest and Disease Report. Sacramento, CA: California Department of Food and Agriculture. p 4-6.

Jain R, Foy CL. 1989. Broomrapes (Orobanche spp.): a potential threat to US broadleaf crops. Weed Technol 3:608-14.

Joel DM, Hershenhorn J, Eizenberg $\mathrm{H}$, et al. 2007. Biology and management of weedy root parasites. Hortic Rev 33:267-

Karačić A, Kohnić A, Đikić $M$ et al 2010. Distribution, biology and control of hemp broomrape (Orobanche ramosa L.). Herbologia 11:1-10.

Kasasian L. 1971. Orobanche spp. Int J Pest Manag 17:35-41.

Kogan M. 1994. Orobanche in Chile: a research report. In: Biology and Management of Orobanche. Proc. 3rd Int Workshop on Orobanche and Related Striga Research. Amsterdam: Royal Tropical Institute p 599-603.

Kroschel J (ed.). 2002. A Technical Manual for Parasitic Weed Research and Extension. Berlin Germany: Springer. 110 p

Lolas PC. 1994. Herbicide for control of broomrape (Orobanche ramosa $L$.) in tobacco (Nicotiana tabacum L.). Weed Res. 34:205-09.

López-Ráez JA, Charnikhova T, Gómez-Roldán V, et al. 2008. Tomato strigolactones are derived from carotenoids and their biosynthesis is promoted by phosphate starvation. New Phytol 178:863-74.

Mauromicale G, Monaco AL, Longo AM. 2008. Effect of branched broomrape (Orobanche ramosa) infection on the growth and photosynthesis of tomato. Weed Sci 56:574-81.

Mauromicale G, Monaco AL, Longo AM, Restuccia A. 2005. Soil solarization, a nonchemica method to control branched broomrape (Orobanche ramosa) and improve the yield of greenhouse tomato. Weed Sci 53:877-83.

Melander B, Kristensen JK 2011. Soil steaming effects on weed seedling emergence under the influence of soil type, soil moisture, soil structure and heat duration. Ann Appl Biol 158(2):194-203.

Miyao GM. 2016. Egyptian broomrape eradication effort in California: a progress report on the joint effort of regulators, university, tomato growers and processors. In XIV International Symposium on Processing Tomato. ISHA Acta Horticulturae 1159. San Juan, Argentina. p 139-142.

Mohamed Kl, Papes M, Williams $R$, et al. 2006. Global invasive potential of ten parasitic witchweeds and related Orobanchaceae. Ambio 35:281-89.

Müller-Stöver D, Kroschel J. 2005. The potential of Ulocladium botrytis for biological control of Orobanche spp. Bio Control 33:301-06.

Musselman LJ. 1996. Parasitic weeds in the southern United States. Castanea 61:271-92.

Osipitan OA, Fernarndez-Bayo JD, Hanson BD, Mesgaran MB 2020. Depleting weed seedbank using bio-solarization in tomato fields. In 72nd Annual Conference of California Weed Science Society, Jan. 22-24, 2020. Monterey, CA. p 22.

Panetta FD, Lawes $R$.

2007. Evaluation of the

Australian branched broom-

rape (Orobanche ramosa)

eradication programme. Weed Sci 55:644-51.

Qasem JR, Foy CL. 2007.

Screening studies on the host range of branched broomrape (Orobanche ramosa). J Hort Sci 82:885-92.

Qasem JR. 2009. Parasitic weeds of the Orobanchaceae family and their natural hosts in Jordan. Weed Biol Manag 9:112-22

Sauerborn J, Saxena MC. 1986. A review on agronomy in relation to orobanche problems in faba bean (Vicia faba L.). In Proceedings of a workshop on biology and control of Orobanche. ter Borg SJ (ed.). LH/VPO. Wageningen: the Netherlands. p 160-65.

[USDA-APHIS] USDA Animal and Plant Health Inspection Service. 2019. Weed risk assessment for Phelipanche ramosa (L.) Pomel (Orobanchaceae)-branched broomrape. US Department of Agriculture Plant and Animal Inspection Service. www.aphis. usda.gov/plant health/plant pest_info/weeds/downloads/ 